\title{
ANALISIS PREDIKSI KEBANGKRUTAN PERUSAHAAN DENGAN MODEL GROVER
}

\author{
Aditya Cahya Nugraha Heryanto \\ Universitas Padjadjaran \\ adityacahya142@gmail.com
}

\begin{abstract}
This research aims to determine the results of the analysis of the Grover model in predicting bankruptcy of companies. The object of research was conducted at the company PT Garuda Indonesia. The population in this research is the annual report of PT Garuda Indonesia for period 2011-2017 with the sample used purposive sampling so that the sample in this research is the annual report of PT Garuda Indonesia for period 2014-2017. Data collection techniques using documentation studies and literature studies. Data analysis techniques using the calculation of bankruptcy predictions with Grover model for Company. The results of this research explain that with using the Grover model , PT Garuda Indonesia from 2014-2017 experienced bankruptcy or financial distress. So PT Garuda Indonesia company can be said not in a healthy condition or is experiencing financial crisis. For this reason, PT Garuda Indonesia needs to make efforts to overcome this problem so that future events will not be repeated. These efforts include increasing profits by evaluating company performance, minimizing debt or liabilities and adding company assets

Keywords: Bangkruptcy, Grover Model, Financial Distress, Annual Report
\end{abstract}




\section{PENDAHULUAN}

Bisnis dizaman sekarang semakin berkembang dan menjamur. Berkat dukungan teknologi dan informasi yang kian canggih membuat bisnis semakin digandrungi dan terasa semakin mudah. Pada tahun 2013 sampai dengan tahun 2018 setidaknya sudah berdiri sekitar 604 bisnis startup dan mayoritas startup yang berdiri tersebut sudah berbentuk badan usaha perseroan terbatas (PT) dengan total 504 startup (Kominfo, 2019). Bisnis tidak terlepas dari yang namanya perusahaan. Perusahaan memiliki kaitan dan hubungan yang sangat erat dengan bisnis. Bisnis adalah usaha menjual barang atau jasa yang dilakukan perorangan, kelompok atau organisasi kepada konsumen dengan tujuan untuk memperoleh profit dan benefit. Begitu juga dengan perusahaan dimana tujuan dari perusahaan yaitu untuk mendapatkan profit. Menurut UndangUndang No. 3 Tahun 1982 pasal 1 huruf b menyatakan bahwa perusahaan adalah setiap bentuk usaha yang menjalankan setiap jenis usaha yang bersifat tetap dan terus menerus dan yang didirikan, bekerja serta berkedudukan dalam wilayah Negara Republik Indonesia, untuk tujuan memperoleh keuntungan dan atau laba (Ojk.go.id). Menurut Badan Pusat Statistik (BPS) tercatat ada sebanyak 26,7 juta perusahaan di Indonesia yang dihasilkan dari sensus ekonomi tahun 2016. Angka ini mengalami peningkatan jika dibandingkan dengan hasil sensus ekonomi pada tahun 2006 yang sebanyak 22,7 juta perusahaan (Detik.com, 2017). Tidak menutup kemungkinan angka tersebut akan berubah dan mengalami peningkatan pada tahuntahun yang akan datang dikarenakan dalam
10 terakhir saja perusahaan yang berdiri di Indonesia mengalami peningkatan yang cukup pesat.

Namun, dizaman ini tidak ada yang pasti apakah perusahaan yang telah berdiri tersebut akan tetap berdiri atau tidak. Karena pola pikir masyarakat sudah berkembang dan kemudahan akan akses teknologi informasi membuat perusahaan saat ini tidak mudah lagi dalam memperoleh keuntungan yang diharapkan. Banyak sekali persaingan diantara perusahaan-perusahaan sehingga tak jarang memicu suatu konflik. Perusahaan yang manajemennya baik dan efisien akan mampu bertahan dibandingkan dengan perusahaan yang manajemennya buruk. Salah satu cara agar perusahaan bisa bertahan dan survive yaitu dari segi pengelolaan keuangan. Banyak sekali perusahaan besar yang manajernya kurang memerhatikan dan salah dalam pengelolaan dan perencanaan keuangan perusahaan. Tak jarang perusahaan tersebut akan mengalami fase atau kondisi dimana arus kas dari perusahaan tersebut mengalami hasil yang negatif dalam kurun beberapa waktu dan sulit untuk membayar kewajibannya. Kondisi tersebut dinamakan dengan kesulitan keuangan atau financial distress. Financial distress jika tidak ditanggulangi dengan cepat maka akan berakibat fatal bagi perusahaan. Dikutip dari bisnis.com sepanjang tahun 2017 saja sudah terdapat delapan perusahaan yang dinyatakanpailit akibat dari kesulitan keuangan atau financial distress yang dihadapinya.

Kondisi financial distress

dikelompokan menjadi dua yaitu solvent dan insolvent. Pada kondisi financial distress ini secara financial, perusahaan akan mengalami arus kas yang minimum dan kemungkinan besar perusahaan akan mengalami kesulitan 
dalam membayar kewajibannya. Selain itu, dampak buruk apabila perusahaan mengalami financial distress yaitu akan mengalami dead weight losses (Achsani et al., 2010). Biasanya perusahaan yang mengalami financial distress akan mengalami rasio profitabilitas yang negatif. Selain itu, rasio likuiditas perusahaan umumnya berada di bawah 1, yang berarti aset lancar perusahaan tidak mampu menutupi utang lancar perusahaan. Kemudian, rasio leverage perusahaan pada umumnya lebih besar dari 1 , artinya jumlah utang perusahaan lebih besar dibandingkan total aset perusahaan. Madeh Salevi (2014) menyatakan kegunaan informasi jika suatu perusahaan mengalami financial distress sebagai berikut : 1) mempercepat tindakan manajemen mencegah masalah sebelum terjadinya kebangkrutan; 2) pihak manajemen dapat mengambil tindakan merger atau take over agar perusahaan lebih mampu untuk membayar hutang dan mengelola perusahaan dengan lebih baik; dan 3) memberikan tanda peringatan awal adanya kebangkrutan pada masa yang akan datang. Maka dari itu, diperlukan suatu strategi dan juga kebijakan dari manajemen perusahaan untuk dapat mengatasinya sebelum perusahaan mengalami dampak yang lebih buruk seperti kebangkrutan sebagai akibat dari tidak dilakukannya tindakan yang cepat dalam hal tersebut (Faradila \& Aziz, 2019).

Pada kasus-kasus kemarin publik dihebohkan dengan laporan keuangan PT Garuda Indonesia yang mencetak rugi yang cukup besar. Dikutip dari Kompas.com pada tahun 2014, PT Garuda Indonesia mengalami kerugian sebesar 371,9 juta dollar AS atau sekitar Rp 4,87 triliun dalam kurs Rp 13.100. Karena adanya tekanan dari pihak eksternal dan internal sehingga dapat membuat kinerja perusahaan melemah. Pada tahun 2015, PT Garuda indonesia perlu bernapas lega karena pada tahun tresebut bisa memperoleh laba bersih sebesar 77,97 juta dollar AS atau sekitar Rp 1,075 triliun dalam kurs 13.788. Penyebab PT Garuda Indonesia bisa memperoleh laba tersebut karena telah terjadi penyusutan beban usahanya. Pada tahun 2016, PT Garuda Indonesia mendapatkan laba sebesar 9,36 juta dollar As atau sekitar Rp 124,5 Miliar meski begitu pada kuartal III mengalami kerugian sebesar 43,6 juta dollar As. Pada Tahun 2017, PT Garuda Indonesia mengalami kerugian sebesar 216,58 juta dollar AS atau sekitar RP 2,98 triliun. Kemudian tahun 2018, PT Garuda Indonesia kembali lagi mencatatkan kerugian sekitar 175,02 juta dollar AS atau sekitar Rp 2,45 triliun.

Dari data tersebut PT Garuda dapat dikatakan setiap tahunnya mengalami kerugian. Oleh karena itu, untuk mengetahui apakah PT Garuda akan mengalami kondisi financial distress atau bahkan kebangkrutan maka perlu dilakukan analisis prediksi kebangkrutan.

Sebelum melakukan analisis kebangkrutan pada perusahaan terlebih dahulu perusahaan harus memiliki laporan keuangan. Laporan keuangan adalah bentuk informasi keuangan yang berupa catatan atau laporan pada suatu periode akuntansi yangdigunakan sebagai gambaran kinerja suatu perusahaan (wikipedia.org). Laporan keuangan sangat krusial dan penting karena didalam laporan keuangan menyajikan beberapa data atau informasi financial suatu perusahaan seperti neraca, laporan laba rugi, laporan arus kas, dan lain-lain. Laporan keuangan berguna bagi pihak eksternal seperti investor untuk bisa melihat apakah perusahaan tersebut memiliki laporan keuangan yang sehat dan memiliki prospek 
yang bagus sehingga investor dapat menilai perusahaan tersebut layak atau tidaknya untuk diberikan dana investasi sebagai penanaman modal investor. Sebelum melakukan hal tersebut, seorang investor perlu melakukan suatu analisis pada laporan keuangan tersebut. Analisis laporan keuangan dapat dilakukan baik oleh investor maupun perusahaan.

Analisis laporan keuangan penting dilakukan perusahaan untuk dapat mengetahui keuntungan dan resiko yang dihadapi oleh suatu perusahaan, apabila terjadi tanda-tanda kebangkrutan sehingga perusahaan dapat melakukan tindakan antisipasi dengan cepat agar tidak sampai terjadi kebangkrutan pada perusahaan tersebut (Pane, 2015).

Kemudian, laporan keuangan digunakan sebagai bahan evaluasi manajer keuangan dalam pengambilan keputusan untuk kedepannya. Selain itu, laporan keuangan juga dapat digunakan sebagai alat dalam memprediksi kebangkrutan suatu perusahaan. Menurut Sembiring (2016) Salah satu alat yang bisa digunakan untuk mengetahui kondisi perusahaan sejak awal yaitu analisis kebangkrutan perusahaan. Analisis Kebangkrutan adalah analisis yang digunakan untuk memperoleh tanda-tanda awal mengenai kebangkrutan. Analisis kebangkrutan berguna untuk memprediksi apakah suatu perusahaan mengalami kebangkrutan atau tidak dimasa yang akandatang, sehingga perusahaan dapat mengantisipasi sebelumnya dengan berbagai perbaikan kinerja perusahaan (Sembiring, 2016).

Menurut Peter dan Yoseph (2011) terdapat beberapa model yang sering digunakan dalam memprediksi kebangkrutan pada perusahaan seperti model Altman Z- score, model Springate, dan model Zmijewski (Jurnal \& Akuntansi, 2011). Analisis modelmodel tersebut terkenal dengan caranya yang mudah digunakan dan tingkat akurasi pun cukup akurat sehingga banyak sekali peneliti lain yang menggunakan model-model tersebut dalam menganalisis kebangkrutan pada suatu perusahaan. Analisis kebangkrutan dilakukan sebagai penilaian dan pertimbangan akan kondisi suatu perusahaan. Penelitian terdahulu mengenai analisis kebangkrutan sudah banyak dilakukan dengan berbagai model yang digunakan. Pada penelitian kali ini penulis akan menggunakan salah satu model yang dapat digunakan dalam memperediksi kebangkrutan perusahaan yaitu model grover. Dari uraian yang telah dibahas diatas maka rumusan masalah dalam penelitian ini yaitu apakah tredapat tanda-tanda kebangkrutan pada perusahaan PT Garuda Indonesia atau tidak. Penelitian ini bertujuan untuk mengetahui hasil analisis dengan menggunakan model gover dalam memprediksi kebangkrutan pada perusahaan PT Garuda Indonesia tahun 2014-2017. Maka dari itu, peneliti akan memberi judul pada penelitian ini sebagai berikut: "Analisis Prediksi Kebangkrutan Perusahaan dengan Model Grover (Studi Pada Perusahaan PT Garuda Indonesia tahun 20142017)".

\section{KAJIAN PUSTAKA DAN PENGEMBANGAN HIPOTESIS}

\section{Kajian Pustaka}

Financial Distress

Menurut Beaver (1966) "financial distress or failure is defined as the inability of a firm to pay its financial obligations as they mature. Operationally, a firm is said to have failed when any of the following events have occurred: bankruptcy, bond default, an 
overdrawn bank account, or nonpayment of a preferred stock dividend". Jadi kegagalan diartikan sebagai ketidakmampuan perusahaan untuk membayar kewajiban keuangannya saat jatuh tempo. Sebuah perusahaan dikatakan telah gagal ketika mengalami kondisi: kebangkrutan, gagal bayar obligasi, rekening bank yang ditarik berlebihan, atau tidak dibayarkannya dividen saham (Beaver, n.d.).

Menurut Platt dan Platt (2002) "Financial distress is defined as a late stage of corporate decline that precedes more cataclysmic event such as bangkruptcy or liquidation". Financial distress didefinisikan sebagai tahap akhir dari penurunan suatu perusahaan sebelum mengalami peristiwa yang lebih dahsyat seperti bangkrut atau likuidasi (Piatt \& Piatt, 2002).

Menurut Beaver et. al (2010) "financial distress refers to the inability of a company to pay its financial obligations as they mature". Artinya financial distress mengacu pada ketidakmampuan perusahaan untuk membayar kewajiban keuangannya saat jatuh tempo (Beaver, 2010).

\section{Laporan Keuangan}

Menurut Hery (2016) Laporan keuangan adalah hasil proses akuntansi yang digunakan sebagai instrumen untuk mengkomunikasikan data keuangan atau aktivitas perusahaan kepada pihak-pihak yang berkepentingan seperti pihak internal dan eksternal, dimana laporan keuangan tersebut dapat menunjukan kondisi kesehatan keuangan perusahaan dan kinerja perusahaan (Fauzan \& Sutiono, 2017).

Laporan Keuangan adalah suatu informasi keuangan yang dihasilkan oleh suatu perusahaan pada periode akuntansi yang digunakan untuk menggambarkan kinerja perusahaan tersebut. Berdasarkan Pernyataan Standar Akuntansi Keuangan
(PSAK) no. 1 (Revisi 2009) tujuan dari penyusunan laporan keuangan adalah "memberikan informasi mengenai posisi keuangan, kinerja keuangan, dan arus kas entitas yang bermanfaat bagi pengguna laporan keuangan".

Hasil dari proses akuntasi adalah laporan keuangan yang merupakan cerminan prestasi manajemen suatu perusahaan pada periode tertentu. Selain digunakan sebagai alat pertanggungjawaban, laporan keuangan juga diperlukan sebagai dasar dalam pengambilan keputusan ekonomi. Menurut Ikatan Akuntan Indonesia (2009), laporan keuangan bertujuan untuk :

1. Menyediakan informasi yang menyangkut posisi keuangan, kinerja, serta perubahan posisi keuangan suatu perusahaan yang bermanfaat bagi sejumlah besar pemakai dalam pengambilan keputusan.

2. Laporan keuangan tidak menyediakan semua informasi yang mungkin dibutuhkan pemakai dalam mengambil keputusan ekonomi karena secara umum menggambarkan pengaruh keuangan dan kejadian masa lalu, dan tidak diwajibkan untuk menyediakan informasi nonkeuangan.

3. Laporan keuangan juga menunjukkan apa yang telah dilakukan manajemen (stewardship), atau pertanggungjawaban manajemen atas sumber daya yang dipercayakan kepadanya (Sari, 2015).

\section{Analisis Kebangkrutan}

Menurut Gitman and Zutter (2015) dalam bukunya kegagalan bisnis merupakan " $A$ business failure is an unfortunate circumstance. Although the majority of firms that fail do so within the first year or two of life, other firms grow, mature, and fail much later. The failure of a business can be viewed in a number of ways and can result from one or more causes". Jadi Kegagalan bisnis adalah keadaan yang tidak menguntungkan. Dimana biasanya terjadi 
di tahun pertama atau kedua berdirinya perusahaan tersebut (tumbuh, matang dan gagal kemudian). Kegagalan bisnis dapat dilihat dalam beberapa cara dan dapat disebabkan oleh satu atau lebih penyebab (Gitman \& Zutter, 2015). Menurut Altman, Hotchkiss, dan Wang (2019) dalam bukunya ada berbagai istilah untuk menggambarkan kondisi

kesulitan keuangan. Terdapat empat istilah yang biasa digunakan yaitu failure, insolvency, default, and bankruptcy.

\section{Failure}

Kegagalan, dalam arti ekonomi, berarti bahwa tingkat pengembalian yang direalisasikan atas modal yang diinvestasikan, dengan penyisihan untuk pertimbangan risiko, secara signifikan lebih rendah daripada tingkat yang berlaku pada investasi serupa. Istilah kegagalan bisnis diadopsi oleh Dun \& Bradstreet (D\&B). Menurut D\&B pengertian Kegagalan bisnis adalah kondisi dimana bisnis berhenti beroperasi akibat dari adanya kebangkrutan pada bisnis tersebut.

2. Insolvency

Insolvensi adalah istilah lain yang menggambarkan kinerja perusahaan yang negatif dan umumnya digunakan dengan cara yang lebih teknis. Teknis insolvensi ada ketika perusahaan tidak dapat memenuhi utangnya saat jatuh tempo. Namun, ini mungkin merupakan gejala arus kas atau kekurangan likuiditas, yang dapat dipandang sebagai kondisi sementara, bukan kondisi kronis. Kepailitan mengacu pada total kewajiban melebihi penilaian wajar dari total aset. Karenanya, kekayaan bersih perusahaan adalah negatif. Kondisi ini memiliki implikasi untuk bagaimana dan apakah perusahaan akan merestrukturisasi, dan memerlukan analisis komprehensif baik nilai kelangsungan usaha dan likuidasi.

\section{Default}

Default mengacu pada peminjam yang melanggar perjanjian dengan kreditor, sebagaimana ditentukan dalam kontrak dengan pemberi pinjaman. Teknis default terjadi ketika perusahaan melanggar ketentuan selain dari pembayaran yang dijadwalkan, misalnya, dengan melanggar perjanjian seperti mempertahankan rasio lancar minimum saat ini atau rasio utang maksimum. Pada kenyataannya, default seperti itu biasanya dinegosiasi ulang dan digunakan untuk menandakan kinerja perusahaan yang memburuk. Ketika suatu perusahaan melewatkan pinjaman yang dijadwalkan atau pembayaran obligasi, biasanya kewajiban bunga periodik, secara hukum default lebih mungkin, meskipun itu tidak selalu ada dalam kasus pinjaman. Pembayaran bunga dapat dilewatkan dan bertambah ke pemberi pinjaman dalam transaksi pribadi, seperti pinjaman bank, tanpa pernyataan formal yang dinyatakan. Namun, untuk obligasi yang dimiliki publik, ketika perusahaan melewatkan pembayaran bunga atau pelunasan pokok, dan masalahnya tidak sembuh dalam masa tenggang, biasanya 30 hari, kemudian menjadi default. Perusahaan dapat terus beroperasi ketika mencoba untuk melakukan restrukturisasi dengan kreditor dan menghindari pernyataan dan pengajuan kebangkrutan formal. Bahkan dimungkinkan untuk menyetujui restrukturisasi dengan jumlah yang cukup dan jumlah penuntut kemudian secara hukum mengajukan kebangkrutan

4. Bangkruptcy 
Perusahaan bisa disebut bangkrut ketika kewajibannya melebihi nilai going concern dari asetnya. Sampai suatu perusahaan menyatakan kebangkrutan di pengadilan kebangkrutan federal, disertai dengan sebuah petisi baik untuk melikuidasi asetnya. Kebangkrutan terjadi ketika nilai yang dinyatakan dari kewajiban perusahaan melebihi nilai pasar wajar dari asetnya. Perusahaan yang bangkrut memiliki ekuitas pemegang saham negatif, yang berarti bahwa klaim kreditor tidak dapat dipenuhi kecuali aset perusahaan dapat dilikuidasi lebih dari nilai buku mereka. Meskipun kebangkrutan adalah bentuk kegagalan yang nyata, pengadilan memperlak

ukan kebangkrutan dan kegagalan dengan cara yang sama. Keduanya dianggap mengindikasikan kegagalan keuangan perusahaan .

Perusahaan yang mengalami financial distress atau kebangkrutan dipengaruhi oleh dua faktor yaitu faktor internal dan faktor eksternal. Faktor internal terdiri atas kinerja keuangan dan capital asset management perusahaan yang tidak baik sehingga perusahaan tidak dapat menutupi pengeluaran atau biaya operasional perusahaan. Kemudian, faktor eksternal terdiri atas kondisi ekonomi lingkungan perusahaan seperti inflasi (Husein \& Pambekti, 2015). Sumber informasi mengenai analisis kebangkrutan bisa diperoleh dari laporan keuangan dengan menggunakan analisis univariate dan multivariate. Pada
Analisis Multivariate bisa menggunakan analisis mode Grover sebagai berikut:

\section{Model Grover}

Model Grover adalah suatu model yang dibuat dengan restorasi (pemulihan) atau pendesainan ulang dari model Altman Z- score. Dibutuhkan X1 dan X3 dari model Altman dan kemudian menambahkan rasio profitabilitas yang berupa ROA (Husein \& Pambekti, 2015). Model Grover dibuat oleh Jeffrey S. Grover yang menggunakan sampel sesuai dengan model Altman Z-score dengan menambahkan tiga belas rasio keuangan yang baru (Putra \& Septiani, 2017). Pada model grover memiliki persamaan sebagai berikut: G-score $=1.650 \mathrm{X} 1$ $+3.404 \mathrm{X} 3-0.016 \mathrm{ROA}+0.057$

Keterangan:

$\mathrm{X} 1$ : Working capital/Total assets

$\mathrm{X} 3$ : Earnings before interest and taxes/Total assets

ROA: Net income/Total assets

Pada model Grover ini mengkategorikan perusahaan dalam dua keadaan, Yaitu (1) keadaan mengalami bangkrut jika skor yang diperoleh atau cut off pointnya kurang dari sama dengan -0,02; dan

(2) keadaan tidak mengalami bangkrut jika skor yang diperoleh atau cut off pointnya $\geq 0,01$ (Prihanthini \& Sari, 2013).

\section{METODE PENELITIAN}

\section{Obyek Penelitian}

Pada penelitian ini obyek penelitian yang akan diteliti adalah perusahaan PT Garuda Indonesia.

\section{Jenis Penelitian}

Penelitian ini menggunakan pendekatan kuantitatif dengan jenis penelitiannya yaitu penelitian deskriptif. Menurut Sugiono dan Rusdin (2018) penelitian deskriptif adalah penelitian yang tujuannya untuk mengeksplorasi dan mengklarifikasi suatu fenomena dengan mendeskripsikan sejumlah variabel yang berkenaan dengan masalah yang diteliti. 


\section{Sumber Data}

Sumber data pada penelitian ini berupa data sekunder yang diperoleh dari laporan keuangan tahunan atau annual report perusahaan PT. Garuda Indonesia yang terdapat di website Bursa Efek Indonesia (www.idx.co.id), website resmi perusahaan PT. Garuda Indonesia (www.garuda- indonesia.com)

\section{Populasi dan Sampel}

Menurut Uma Sekaran dan Roger Bougie (2016:236-7) populasi mengacu pada seluruh kelompok orang, peristiwa, ataupun hal-hal menarik yang ingin diselidiki atau diteliti oleh peneliti. Populasi pada penelitian ini berupa seluruh laporan keuangan tahunan perusahaan PT Garuda Indonesia dari tahun 2011-2019.

Sampel adalah bagian dari populasi. Sampel merupakan subkelompok atau subset dari populasi. Dengan mempelajari sampel, peneliti harus dapat menarik kesimpulan yang dapat digeneralisasi untuk populasi yang diminati (Space, 2014). Teknik pengambilan sampel dalam penelitian ini menggunakan purposive sampling. Purposive sampling adalah Pengambilan sampel yang dilakukan pada tipe orang tertentu yang dapat memberikan informasi yang diinginkan peneliti, baik karena mereka satu-satunya yang memiliki informasi tersebut, atau mereka yang sesuai dengan beberapa kriteria yang ditetapkan oleh peneliti (Space, 2014). Maka sampel dalam penelitian ini yaitu laporan tahunan PT. Garuda Indonesia tahun 2014-2018.

\section{Teknik Pengumpulan Data}

Teknik pengumpulan data menggunakan studi dokumentasi dan studi pustaka yang diperoleh dari berita, laporan keuangan, jurnal-jrunal, buku, dan lainlain. Menurut Arikunto (2002:135) dalam Peter dan Yoseph (2011) studi dokumentasi adalah teknik pengumpulan data yang bersumber dari benda-benda tertulis. Studi dokumentasi dalam penelitian ini adalah laporan keuangan PT. Garuda Indonesia tahun 2014-2018.

Studi pustaka adalah teknik yang digunakan dengan memahami literaturliteratur yang berisi bahasan yang berkaitan dengan penelitian dan juga teknik pengumpulan data dari sumber-sumber yang relevan serta membaca buku-buku yang berkaitan dengan penelitian (Peter dan Yoseph, 2011). Studi pustaka dari penelitian ini yaitu jurnal-jurnal, berita, dan buku-buku yang berkaitan dengan penelitian analisi kebangkrutan perusahaan.

\section{Definisi Operasional variabel}

Variabel yang digunakan dalam penelitian ini adalah rasio dari model grover yang meliputi Working capital/Total assets, Earnings before interest and taxes/Total assets, dan Return On Assets (Prihanthini \& Sari, 2013). Variabel-variabel tersebut digunakan untuk menghitung nilai G-Score dalam memprediksi kebangkrutan pada perusahaan PT Garuda Indonesia. Aadapun rumusnya sebagai berikut:

G-score $=1.650 \mathrm{X} 1+3.404 \mathrm{X} 3-0.016 \mathrm{ROA}+$ 0.057

\section{Teknik Analisi Data}

Teknik analisis data pada penelitian ini yaitu teknik analisis data deskriptif. Pengolahan data menggunakan program Microsoft Excel dalam melakukan penghitungan dengan menggunakan model grover untuk memprediksi kebangkrutan perusahaan.

\section{HASIL DAN PEMBAHASAN}

\begin{tabular}{|r|r|}
\hline Tahun & WCTA (X1) \\
\hline 2014 & $-0,217556665$ \\
\hline
\end{tabular}




\begin{tabular}{|r|r|}
\hline 2015 & $-0,336916153$ \\
\hline 2016 & $-0,434785528$ \\
\hline 2017 & $-0,434785528$ \\
\hline
\end{tabular}

Tabel 4.1 WCTA
Berdasarkan tabel 4.1 dapat dilihat bahwa nilai WCTA dari tahun 2014-2017 bernilai negatif artinya aset lancar lebih kecil dari pada kewajiban lancar atau bisa dikatakan juga PT. Garuda tidak mampu membayar utang jangka pendeknya sehingga perusahaan akan kesulitan dalam menjalankankegiatan operasional perusahaannya. Maka dari itu perusahaan perlu meningkatkan atau memaksimalkan hal-hal seperti pendapatan bersih, melakukan penjualan obligasi, perusahaan perlu melakukan right issues (menjual saham baru) untuk memperoleh tambahan modal, dan lain-lain.

Tabel 4

EBITTA

\begin{tabular}{|r|r|}
\hline Tahun & \multicolumn{1}{|c|}{ EBITTA (X2) } \\
\hline 2014 & $-0,438356059$ \\
\hline 2015 & 0,173537032 \\
\hline 2016 & 0,090259143 \\
\hline 2017 & $-0,068907946$ \\
\hline
\end{tabular}

dilihat bahwa Pada tahun 20114 dan 2017 nilai EBITTA mendapatkan nilai negatif masing sebesar -0,4383 dan -0,0689. Artinya dilihat bahwa pada tahun 2014 dan 2017perusahaan tidak begitu efektif menggunakan asetnya untuk mendapatkan/menghasilkan pendapatan. Pada tahun 2015 dan 2016 nilai EBITTA bernilai positif dengan besar masing-masing 0,1735 dan 0,09025 artinya total aset lebih besar dari pada laba operasional. Perhitungan rasio ini memperlihatkan kesehatan keuangan perusahaan dan kemampuan perusahaan dalam membayar kewajibannya.

Tabel 4

RETURN ON ASSET

\begin{tabular}{|c|c|}
\hline Tahun & ROA \\
\hline 2014 & $-0,001919365$ \\
\hline
\end{tabular}




\begin{tabular}{|r|r|}
\hline 2015 & 0,000376913 \\
\hline 2016 & $4,00896 \mathrm{E}-05$ \\
\hline 2017 & $-0,000907247$ \\
\hline
\end{tabular}

ROA PT. Garuda Indonesia memperoleh nilai negatif masing-masing sebesar $-0,001919365$ dan $-0,000907247$ artinya perusahaan tidak memperoleh laba bersih dan bahkan mengalami kerugian. Tahun 2015 dan 2016 ROA PT. Garuda memperoleh nilai positif masing-masing sebesar 0,000376913 dan 4,00896E-05 artinya perusahaan memperoleh laba bersih meski nilainya tidak begitu besar dari total asetnya.

Tabel 4 Hasil G-Score

\begin{tabular}{|r|r|l|}
\hline \multicolumn{1}{|l|}{ Tahun } & G Score & Status \\
\hline 2014 & $-0,596993358$ & Bangkrut \\
\hline 2015 & $-0,106756035$ & Bangkrut \\
\hline 2016 & $-0,287566475$ & Bangkrut \\
\hline 2017 & $-0,445786227$ & Bangkrut \\
\hline
\end{tabular}

Berdasarkan tabel 4.3 diatas dapat penulis dapat memperoleh hasil penelitian mengenai analisis kebangkrutan dengan menggunakan model grover pada perusahaan PT Garuda Indonesia pada tahun 2014-2017, maka dapat disimpulkan bahwa dengan menggunakan model Grover PT Garuda Indonesia dari tahun 2014-2017 mengalami

dilihat bahwa PT. Garuda Indonesia dari tahun 2014-2017 nilai G-score yang digunakan dalam memprediksi kebangkrutan perusahaan memperoleh nilai negatif atau memperoleh nilai kurang dari nilai cut off sebesar $-0,02$ artinya perusahaan dalam keadaan tersebut mengalami financial distress atau kebangkrutan. Dimana perusahaan banyak mengalami kerugian dan juga memiliki utang atau kewajiban yang besar.

\section{SIMPULAN}

Berdasarkan identifikasi masalah yang telah dirumuskan diatas dan tujuan penelitian yang ingin dicapai sehingga kebangkrutan atau financial distress. Maka perusahaan PT Garuda dapat dikatakan tidak dalam kondisi sehat atau sedang mengalami kririsi keuangan. Untuk itu PT Garuda Indonesia perlu melakukan upayaupaya untuk bisa mengatasi masalah tersebut agar kejadian di masa yang akan datang tidak akan terulangi lagi. Upaya-upaya tersebut seperti meningkatkan laba dengan mengevaluasi kinerja perusahaan, meminimalkan utang atau kewajiban dan menambah aset perusahaan. Selain itu, perusahaan perlu membenahi aspek-aspek lain sehingga menciptakan efisiensi dan efektivitas operasional perusahaan sehingga dengan begitu perusahaan bisa dipercaya kembali oleh investor untuk dapat menanamkan modalnya dan juga meningkatkan nilai perusahaan.. Kemudian, penulis juga merekomendasikan kepada penelitian selanjutnya untuk menambah model-model prediksi yang lain.

\section{REFERENSI}

Achsani, N. A., Manurung, A. H., \& Nuryartono, N. (2010). The Dynamics of Corporate Financial Distress in Emerging Market Economy: The Dynamics of Corporate Financial Distress in Emerging Market Economy: Empirical Evidence from the Indonesian Stock Exchange 2004-2008. August 2014.

Altman, E. I., Hotchkiss, E., \& Wang, W. (2019). Corporate Financial Distress, Restructuring, and Bangkruptcy. Hoboken, New Jersey: John Wiley \& Sons, Inc.

Beaver, W. H. (n.d.). Analysis and the Prediction of Financial Distress Financial Statement Analysis and the Prediction of Financial Distress.

Beaver, W. H. (2010). of Failure Financial Ratios as Predictors. Journal of AccountingResearch, 4(1966), 71-111. 
Faradila, P., \& Aziz, A. (2019). Analisa Kinerja

Keuangan Terhadap Prediksi Financial

Distress Ukuran Perusahaan Sebagai

Variabel Kontrol. Jurnal Ekonomi Dan

Bisnis, 3(1), 27.

https://doi.org/10.35590/jeb.v3i1.722

Fauzan, H., \& Sutiono, F. (2017). Perbandingan Model Altman Z-Score, Zmijewski, Springate, dan Grover dalam Memprediksi Kebangkrutan Perusahaan Perbankan (Studi Kasus pada BEI Tahun 2011 - 2015).

Jurnal Online Insan Akuntan, 2(1), 234086.

Gitman, L. J., \& Zutter, C. J. (2015). Principles of Managerial Finance 14th Edition. In Prentice Hall. https://doi.org/10.1016/08908389(89)90087-5

Husein, M. F., \& Pambekti, G. T. (2015). Precision of the models of Altman, Springate, Zmijewski, and Grover for predicting the financial distress. Journal of Economics, Business \& Accountancy Ventura, $\quad 17(3), \quad 405$. https://doi.org/10.14414/jebav.v17i3.362

Jurnal, A., \& Akuntansi, I. (2011). "Analisis Rasio Laporan Keuangan Dan Analisis Kebangkrutan Dengan Metode Z-Score Altman, Springate Dan Zmijewski Pada Pt. April.

Pane, R. (2015). ANALISIS DISKRIMINAN UNTUK MEMPREDIKSI KEBANGKRUTAN PERUSAHAAN (Studi pada Perusahaan Manufaktur yang Terdaftar di Bursa Efek Indonesia Tahun 2011-2013). Jurnal Administrasi Bisnis S1 Universitas Brawijaya, 27(2), 86400.

Piatt, H. D., \& Piatt, M. B. (2002). Predicting corporate financial distress: Reflections on choice-based sample bias. Journal of Economics and Finance, 26(2), 184-199. https://doi.org/10.1007/bf02755985

Prihanthini, N. M. E. D., \& Sari, M. M. R. (2013). Z-SCORE , SPRINGATE DAN ZMIJEWSKI PADA PERUSAHAAN FOOD Fakultas Ekonomi dan Bisnis Universitas Udayana ( UNUD ), Bali , Indonesia Fakultas Ekonomi dan Bisnis Universitas Udayana ( UNUD ), Bali , Indonesia ABSTRAK Perkembangan zaman yang diikuti dengan per. E'jurnal Akuntansi Universitas Udayana, 2, 417-435.
Putra, I. G. S., \& Septiani, R. (2017). Analisis Perbandingan Model Zmijewski Dan Grover Pada Perusahaan Semen Di Bei 2008-2014. Jurnal Riset Akuntansi Dan Keuangan, 4(3), 1143-1154. https://doi.org/10.17509/jrak.v4i3. 67

Sembiring, E. E. (2016). Analisis Keakuratan Model Ohlson dalam Memprediksi

Kebangkrutan (Delisting) Perusahaan yang Terdaftar di BEI. Jurnal Akuntansi Keuangan Dan Bisnis, 9(2), 1-9.

Space, W. L. (2014). International Standard Classification of Occupations (ISCO). Encyclopedia of Quality of Life and WellBeing Research, 3336-3336. https://doi.org/10.1007/978-94-007-07535_102084

Fauzan, H., Sutiono, F. 2017. Perbandingan Model Altman Z-Score, Zmijewski, Springate, dan Grover dalam Memprediksi Kebangkrutan Perusahaan Perbankan: Studi Kasus pada BEI Tahun 2011-2015. Jurnal Online Insan Akuntan. 2(1): 49-60.

Fauzi, M., Diah setiawan, S. R., Fauzi, A., dst. Sering Rugi, Berikut Catatan Kinerja Keuangan Garuda Indonesia 20142019.

https://www.kompas.com/tren/read/2019/12/10/ 154611465/sering-rugi-berikut-catatankinerja- keuangan-garuda-indonesia-20142019?page=all. Diakses tanggal 05 April 2020.

Husein, M. F., Pambekti, G. T. 2014. Precision of the Model of Altman, Springate, Zmijewski, and Grover for Predicting the Financial Distress. Journal of Economics, Business, and Accountancy Ventura. 17(3): 405-416.

Oktaviandri, A., Firli, A., Iradianty, A. . Analisis Prediksi Kebangkrutan dengan Model Altman, Springate, Ohlson, dan Grover pada Perusahaan di Sektor Pertanian Bursa Efek Indonesia Periode 2011-2015. Majalah Ilmiah UNIKOM.

15(1): 71-78.

Pane, R. A., Topowijono, Husaini, A. 2015. Analisis Diskriminan untuk Memprediksi Kebangkrutan Perusahaan (Studi pada Perusahaan Manufaktur yang Terdaftar di Bursa Efek Indonesia Tahun 2011-2013). Jurnal Administrasi Bisnis. 27(2): $1-8$.

Parquinda, L. Azizah, D. F. 2019. Analisis Penggunaan Model Grover (G-Score), Fulmer (H-Score), Springate (S-Score), Zmijewski (X- Score), dan 
Altman (Z-Score) sebagai Predikator Kebangkrutan (Studi Pada Perusahaan Tekstil dan Garmen yang Listing di Bursa Efek Indonesia (BEI) Periode 2015-2017). Jurnal Administrasi Bisnis. 72(1): 110-118.

Peter, Yoseph. 2011. Analisis Kebangkrutan dengan Metode Z-Score Altman, Springate dan Zmijewski pada PT. Indofood Sukses Makmur TBK Periode 2005-2009. Akurat Jurnal Ilmiah Akuntansi. 4(2): 1-20.

Poulus, S., \& Rusdin. 2018. Metodologi Penelitian Sosial. Bandung: CV Alfabeta.

Priambodo, D., Pustikaningsih, A. 2018. Analisis Perbandingan Model Altman, Springate, Grover, dan Zmijewski dalam Memprediksi Financial Distress (Studi Empiris pada Perusahaan Sektor Pertambangan yang Terdaftar di Bursa Efek Indonesia Periode 2012-2015). Jurnal Profita: Kajian Akuntansi. 6(4): 1-10.

Prihanthini, N. M. E. D., Sari, M. M. R. 2013. Prediksi Kebangkrutan dengan Model Grover, Altman ZScore, Springate, dan Zmijewski pada Perusahaan Food and Beverage di Bursa Efek Indonesia. E-Jurnal Akuntansi Universitas Udayana. 5(2): 417-435.
Putra, I. G. S., Septiani, R. 2016. Analisis Perbandingan Model Zmijewski dan Grover Pada Perusahaan Semen di BEI 2008-2014. Jurnal Riset Akuntansi dan Keuangan. 4(3): 1143-1154.

Sari, E.W.P., 2015. Penggunaan model Zmijewski, Springate, Altman Z-Score dan Grover dalam memprediksi kepailitan pada Perusahaan transportasi yang terdaftar di Bursa Efek Indonesia. Skripsi. Universitas Dian Nuswantoro. Semarang.

Sekaran, U., Bougie, R. 2016. Research Methods for Business: a Skill-Building Approach. Edisi 7. John Wiley \& Sons. Chicester, West Sussex- United Kingdom.

Utama, B. I., Sudjana, N., Nurlaily, F. 2018. Analisis Keakuratan Model Ohlson dalam Memprediksi Kebangkrutan (Bangkruptcy) (Studi pada Perusahaan Delisting yang Terdaftar di BEI Periode 2013-2017). Jurnal Administrasi Bisnis. 64(2): 110.

Wikipedia. Laporan Keuangan. https://id.wikipedia.org/wiki/LaporanKeuangan. Diakses tanggal 05 April 2020. 